\title{
Precocious puberty in McCune-Albright syndrome: a case report
}

\author{
Rianti Puji Lestari*, Retno Sutomo, Madarina Julia \\ Department of Child Health, Faculty of Medicine/Dr. Sardjito General Hospital, Universitas \\ Gadjah Mada, Yogyakarta, Indonesia
}

DOI: http://dx.doi.org/10.19106/JMedScie/0050032018014

\begin{abstract}
McCune-Albright syndrome (MAS) is a rare disease characterized by a triad of fibrous dysplasia, cafe-au-lait spots and peripheral precocious puberty. We reported a 5 -year8-month old girl with MAS who has been followed-up for 2 years and 8 months. She was referred to pediatric endocrinology clinic in our hospital for vaginal bleeding at age of 2 years 11 months. She had peripheral precocious puberty, i.e. increased estrogen level associated with very low gonadotropins, and cafe-au-lait spots on her face and was diagnosed as MAS. The patient was treated with estrogen receptor blocker (tamoxifen). She had no menses during the 2 years and 8 months of tamoxifen treatment. Her growth rate and bone maturation were also in normal ranges. However, at the end of tamoxifen treatment she had an episode of vaginal bleeding so that we had to change to other treatment modalities.
\end{abstract}

\section{ABSTRAK}

Sindrom McCune-Albright merupakan penyakit langka yang ditandai dengan trias displasia fibrosa, makula cafe-au-lait dan pubertas prekok perifer. Kami melaporkan anak perempuan usia 5 tahun 8 bulan yang telah kami amati selama 2 tahun 8 bulan. Pasien datang ke poliklinik endokrinologi di rumah sakit kami dengan keluhan perdarahan pervaginam pada usia 2 tahun 11 bulan. la mengalami pubertas prekok perifer yang ditandai dengan peningkatan kadar estrogen dan rendahnya kadar gonadotropin,, makula cafe-au-lait, dan didiagnosis dengan sindrom McCune-Albright. Pasien diterapi dengan penghambat reseptor estrogen (tamoxifen). Selama terapi, siklus menstruasi terhenti, kecepatan pertumbuhan dan maturasi tulang dalam batas normal. Namun pada akhir terapi dengan tamoxifen, pasien kembali mengalami perdarahan pervaginam sehingga kami harus mengganti dengan modalitas terapi yang lain.

Keywords: McCune-Albright syndrome - precocious puberty - tamoxifen - genetic disorders - gonadotropins

\section{INTRODUCTION}

McCune-Albright syndrome (MAS) is a genetic disorder characterized by abnormalities in skin pigmentation, endocrine system, and bone growth due to the GNAS (guanine nucleotide binding protein, alpha stimulating) gene mutations. ${ }^{1,2}$ Prevalence of the disease ranged from 1:100.000 to
1:1.000.000 worldwide. ${ }^{3}$ Classically, this syndrome presents with triad of fibrous dysplasia, typical skin pigmentation (cafeau-lait), and endocrinopathies, including precocious puberty, hyperthyroidism, Cushing's syndrome, growthhormoneexcess, hyperprolactinemia, hyperparathyroidism, and/or rickets or osteomalacia. 
Precocious puberty was the most common endocrinopathy found in MAS. It occurs in $64-79 \%$ of girls and $15 \%$ of boys. ${ }^{4}$ Aromatase inhibitors, e.g. testolactone, fadrazole, anastrozole, and letrozole, selective estrogen receptor modulators, e.g. tamoxifen, analogue of gonadotropin-releasing hormone $(\mathrm{GnRH})$, and surgery were, so far, the suggested modalities to manage precocious puberty associated with MAS. ${ }^{5}$ However, due to the rareness of the disease, the experience of using any of the above modalities are very limited. In this case report, we present a 2-years-8-month follow-up of tamoxifen use in a patient with peripheral precocious puberty of MAS.

\section{CASE}

A 2-years-11-month-girl, presented to pediatric endocrinology clinic at Sardjito General Hospital due to vaginal bleeding.
The bleeding last for 2-3 days. On physical examination, we found breast enlargement (Tanner stage 2) and cafe-au-lait spots on her face. The child's height was $87,0 \mathrm{~cm}$ (plotted at -1.8 SD on the WHO child growth standard 2006). We observed low levels of gonadotropins, i.e. luteinizing hormone (LH) $<0.1 \mathrm{mIU} / \mathrm{mL}$ (normal values: 2.4$12.6 \mathrm{mIU} / \mathrm{mL}$, follicle-stimulating hormone (FSH) of $0.109 \mathrm{mIU} / \mathrm{mL}$ (normal values: 3.5-12.5 $\mathrm{mIU} / \mathrm{mL}$ ) and increased level of estradiol (635 pg/mL, normal values: 6-20 $\mathrm{pg} / \mathrm{mL}$ ). Bone age, assessed by GreulichPyle method, was equivalent to 2 years old. Pelvic ultrasound examination revealed post pubertal uterine size $(2.57 \times 2.67 \times 1.73 \mathrm{~cm})$, however, the ovaries were unvisualized. There was no history of pathological fracture. Based on the presence of peripheral precocious puberty and cafe-au-lait spots on the face, patient was diagnosed as MAS.
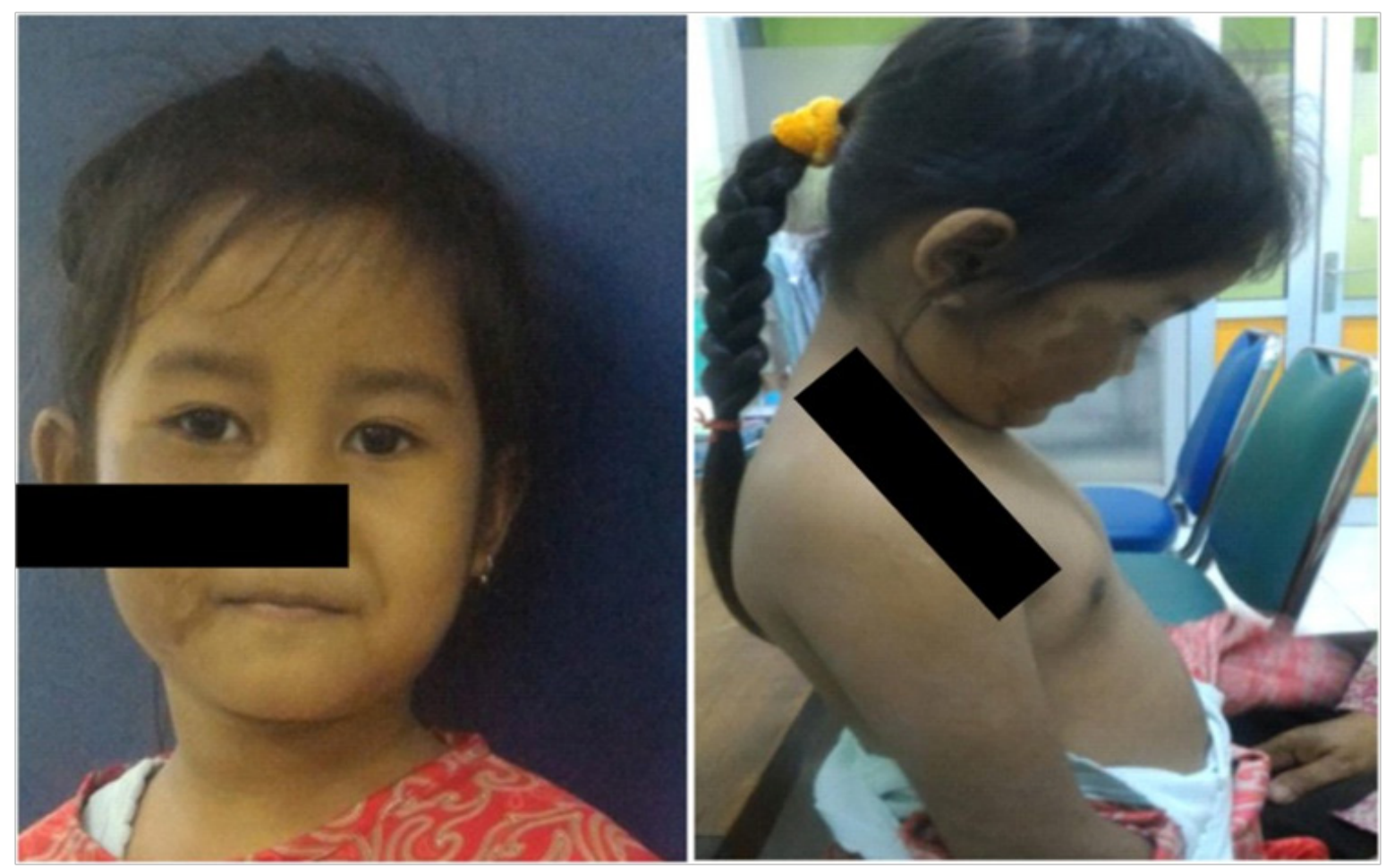

FIGURE 1. Cafe-au-lait skin pigmentation on the face 
Treatment with tamoxifen $(20 \mathrm{mg} /$ day) was started immediately following the diagnosis. The menstrual bleeding was ceased shortly after the initiation of therapy. The serum estradiol level measured one year after the treatment declined to less than $5 \mathrm{pg} /$ $\mathrm{mL}$. Pelvic ultrasound examination carried out one year after the treatment showed smaller uterine size $(2.71 \times 2.21 \times 1.20 \mathrm{~cm})$. The ovaries were also unvisualized.

After 2 years and 8 months of regular treatment with single dose of tamoxifen $20 \mathrm{mg} /$ day, the child had an episode of vaginal bleeding and breast enlargement, accompanied by pubic hair growth (Tanner stage 2). Evaluation of endocrine function observed low levels of gonadotropins ( $\mathrm{LH}$ $0.1 \mathrm{mIU} / \mathrm{mL}, \mathrm{FSH} 0.8 \mathrm{mIU} / \mathrm{mL}$ ) and normal level of estradiol $(5 \mathrm{pg} / \mathrm{mL})$. Bone age was equivalent to 5 years old, which was still inline for chronological age of 5 years and 8 months. On pelvic ultrasound examination, the uterine size increased compared to the last evaluation $(3.79 \times 2.17 \times 1.96 \mathrm{~cm})$, and the ovaries were still unvisualized.

The child has been growing well. Currently, at the age of 5 years and 8 months, she was $112.0 \mathrm{~cm}$ in height and $19.0 \mathrm{~kg}$ in weight (equal to $-0.8 \mathrm{SD}$ and $-0.5 \mathrm{SD}$, respectively, on the WHO growth standard 2006), and has achieved Tanner stage of B2 and P2. The growth velocity was $7.5 \mathrm{~cm} /$ year during the last 2 years $(95 \%$ confidence interval of growth velocity in pre-pubertal girls is $5.1-9.3 \mathrm{~cm} /$ year). During the observation, no other endocrinopathies that often accompany MAS (Cushing's syndrome, hyperprolactinoma, hyperthyroidism, and growth hormone excess) were observed. Thyroid ultrasound, and TSH and FT4 levels were normal. There were no bone abnormalities suggesting fibrous dysplasia. No pathological fracture was observed, but at the age of 4 years there was an open second metatarsal fracture on the left foot, coincidently due to motorcycle accident. The fracture completely healed without deformity or gait impairment after surgical treatment of open reduction and internal fixation.

\section{DISCUSSION}

MAS is characterized by a triad of fibrous dysplasia, cafe-au-lait spots, and precocious puberty. Other endocrinopathies such as hyperthyroidism, growth hormone excess, Cushing's syndrome, hyperprolactinemia, and rickets or osteomalacia may also occur, as well as other involvement of the liver, parathyroid, pancreas, and heart. ${ }^{6}$ MAS is associated with mutation in the GNAS1 gene, which is mapped to chromosome 20q13.3. The protein product is involved in G-protein signaling. ${ }^{2}$ The mutation in the GNAS gene occurs randomly during pregnancy and will result in mosaic of normal and mutated cells. ${ }^{1,7}$ The manifestation and the severity of this disease depends on the number and the location of the cells expressing the mutated gene. The mutation influences activity of the related organ system at the level of interaction between hormones and receptor. ${ }^{2}$

Precocious puberty is the most common endocrinopathy found in MAS. Precocious puberty affects more girls than boys, characterized by premature vaginal bleeding. The precocious puberty was peripheral in origin, that is the hypothalamicpituitary-gonadal axis was not active. The pathogenesis involves autonomous activation of ovarian tissue lead to estrogen hypersecretion. However, progression into central precocious puberty may also occur. ${ }^{5,8}$

Therapeutic options include the use of anti-estrogen (aromatase inhibitor, e.g. testolactone, fadrozole, anastrozole, andletrozole), estrogen receptor inhibitor (e.g.tamoxifen), analogue of GnRH(ifthere is a progression to central precocious puberty), and surgery (unilateral oophorectomy, cystectomy). ${ }^{5}$ A multicenter study on the use of tamoxifen for precocious puberty in girls with MAS for one year has shown a decrease in vaginal bleeding episodes and significant improvements of growth velocity and bone maturation. ${ }^{9}$

We treated our patient with tamoxifen and observed good response during the first and second year of treatment. She had no menses, and her growth rate and 
bone maturation were in normal ranges. However, on third year (after 2-years-and8-month treatment) she suddenly had new episode of vaginal bleeding and breast enlargement, accompanied by pubic hair growth, despite regular treatment with tamoxifen. In fact, the patient had good adherence to the treatment, as we evaluated using the Medication Morisky Adherence scale (MMAS-8). ${ }^{10}$ We decided to change to other treatment modalities since, to the best of our knowledge, there is no study so far on the safety of using higher dose of tamoxifen. Hormonal evaluation after the vaginal bleeding revealed no increase in gonadotropin level, therefore, progression to central precocious puberty can be ruled out.

Nunez et al. ${ }^{11}$ reported that fadrazole was not effective for the treatment of precocious puberty and causing adrenal insufficiency. Meanwhile, Feuillan et al. ${ }^{12}$ reported that testolactone may be used as a therapy for precocious puberty since it leads to a decrease in ovarian volume and estrogen concentration. However, one study $^{13}$, which evaluates the long-term therapy of testolactone, shows some patients have persistent symptoms of puberty, suggesting incomplete inhibitory effects of estrogen production. Other study ${ }^{14}$ indicates that letrozole is an effective medication for precocious puberty in MAS. Recently, Estrada et al. ${ }^{15}$ shows that letrozole has good long-term effect for precocious puberty in MAS in reducing episodes of menstruation and keeping the skeletal maturation and growth velocity so that predicted adult height can be achieved.

Based on those recent studies on the long-term effects letrozole in girls with precocious puberty in MAS, we changed the medication for our patient to letrozole following the failure of two-year-treatment with tamoxifen. We started the treatment with letrozole at dose of $1.25 \mathrm{mg} /$ day since March 2017, and continuing to observe the result.

\section{CONCLUSION}

The diagnosis of MAS must be kept in mind in cases with gonadotropinindependent precocious puberty. Radiologic and laboratory assessments should be performed in order to investigate the presence of accompanying endocrinological and non-endocrinological disorders. A careful clinical observation and follow up of patients with mentioned clinical presentations is necessary.

\section{ACKNOWLEDGEMENTS}

We would like to thank the patient and her parents for allowing us to share her details.

\section{REFERENCES}

1. Collins MT, Singer FR, Eugster E. McCune-Albright syndrome and the extraskeletal manifestations of fibrous dysplasia. Orphanet J of Rare Diseases 2012; 7 (Suppl 1): S4. http://dx.doi.org/10.1186/1750-1172-7-S1-S4

2. Collins MT, Sarlis NJ, Merino MJ, Monroe J, Crawford SE, Krakoff JA, et $a l$. Thyroid carcinoma in the McCuneAlbright syndrome: the contributory role of Gs alpha activating mutations. J Clin Endocrinol Metab. 2003; 88: 4413-4417. https://doi.org/10.1210/jc.2002-021642

3. Collins MT. McCune-Albright Syndrome. Obtained from: www.orpha. net/patho/GB/uk-McCune-AlbrightSyndrome.pdf

4. Volkl TM, Dorr HG. McCune-Albright syndrome: clinical picture and natural history in children and adolescents. J Pediatr Endocrinol Metab 2006; 19: 551-559. http://dx.doi.org/10.1515/JPEM.2006.19.S2.551

5. Mieszczak J, Eugster EA. Treatment of precocius puberty in McCune-Albright syndrome. Ped Endocrinol. 2007; 4: 419-422.

6. Aycan Z, Onder A, Cetinkaya S. Eightyear follow-up of a girl with McCuneAlbright syndrome. J Clin Res Ped Endo. 2011;3(1):40-42.

http://dx.doi.org/10.4274/jcrpe.v3i1.09 
7. Siadati S, Shafigh E. McCune-Albright syndrome: A case report. Iranian Medicine 2010; 13 (3): 245-247.

8. Matarazzo P, Lala R, Andreo M, Einauidi S, Altare F, Viora E, et al. McCuneAlbright syndrome: the persistence of autonomous ovarian hyperfunction during adolesance and early adult age. J Pediatr Endocrinol Metab 2006; 19: 607-617. http://dx.doi.org/10.1515/JPEM.2006.19.S2.607

9. Eugster EA, Rubin SD, Reiter EO, Plourde P, Jou HC, Pescovitz $\mathrm{OH}$, et al. Tamoxifen treatment for precociuos puberty in McCune-Albright syndrome: a multicenter trial. J Pediatr. 2003; 143: 60-6. http://x.doi.org/10.1016/S0022-3476(03)00128-8

10. Morinsky DE, Muntner P. Medication adherence scale versus pharmacy fill rates in senior with hypertension. Am J Manag Care 2009;15(1):59-66.

11. Nunez S, Calis K, Cutler G, Jones J, Feuillan P. Lack of efficicacy of fadrazole in treating precocius puberty in girls with the McCune- Albright syndrome. J Clin Endocrinol Metab. 2003; 88: 5730-5733. http://dx.doi.org/10.1210/jc.2003-030864
12. Feuillan P, Foster C, Pescovitz O, Hench $\mathrm{K}$, Shawker T, Dwyer A, et al. Treatment of precocious puberty in the McCune Albright with the aromatase inhibitor testolactone. N Eng J Med. 1986; 315: 1115-1119. http:/dx.doi.org/10.1056/NEJM198610303151802

13. Feuillan PP, Jones J, Cutler GB. Long term testolactone therapy for precocious puberty in girls with the McCuneAlbright syndrome. J Clin Endocrinol Metab. 1993; 77 (3): 647-651. http://dx.doi.org/10.1210/jcem.77.3.8370686

14. Feuillan P, Calis P, Hill S, Shawker T, Robey P, Collins M. Letrazole treatment of precocious puberty in girls with the McCune-Albright syndrome: a pilot study. J Clin Endocrinol Metab. 2007; 92: 2100-2106.

http://dx.doi.org/10.1210/jc.2006-2350

15. Estrada A, Boyce AM, Brillante BA, LC Guthrie, Gafni RI, Collins MT. Longterm outcomes of letrozole treatment for precocious puberty in girls with McCune-Albright syndrome. Eur J Endocrinol. 2016; 175(5): 477-483. http://dx.doi.org/10.1530/EJE-16-0526 